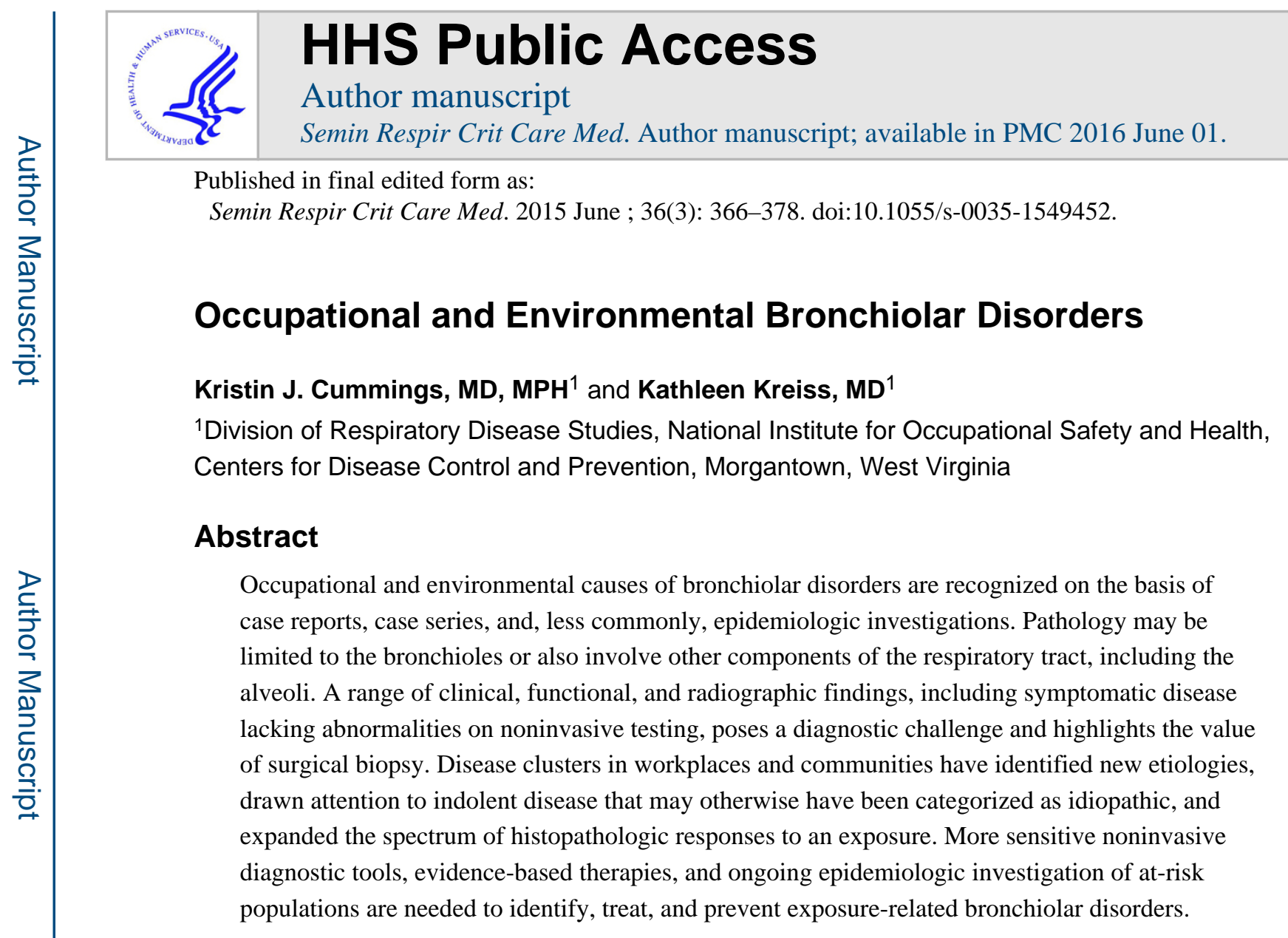

\title{
Keywords
}

bronchiolitis; BOOP; exposure; lung function; biopsy

\begin{abstract}
Bronchiolar disorders encompass a spectrum of diseases involving the small airways $(<2$ $\mathrm{mm}$ in diameter). ${ }^{1}$ Pathology may be limited to the bronchioles or also involve other components of the respiratory tract, including the alveoli. The varied clinical, functional, and radiographic findings of bronchiolar disorders, including symptomatic disease lacking abnormalities on noninvasive testing, pose a diagnostic challenge. Furthermore, the variability in presentation likely hinders the identification of occupational and environmental causes of bronchiolar disorders. Indeed, it is only in recent years that the traditional view of exposure-related bronchiolar disorders as acute sequela of overwhelming accidental exposures has given way to a more nuanced picture that includes disease of insidious onset without a recognized overexposure event. The occurrence and investigation of unanticipated disease clusters among workers or community members with shared exposures have been instrumental to this evolution.
\end{abstract}

The description of bronchiolar disorders is notable for a preponderance of terms that are inconsistently defined and used, inviting confusion. The term bronchiolitis indicates an inflammatory condition centered on the bronchioles. ${ }^{2}$ Cellular bronchiolitis is a useful term

\footnotetext{
Address for correspondence Kristin J. Cummings, MD, MPH, Division of Respiratory Disease Studies, National Institute for Occupational Safety and Health, Centers for Disease Control and Prevention, 1095 Willowdale Road, MS 2800, Morgantown, WV 26505 (cvx5@cdc.gov).
} 
to describe any cellular inflammatory infiltrate of the bronchioles; it can be acute, chronic, or follicular if germinal centers are present; respiratory with intraluminal and intra-alveolar pigmented macrophages; or necrotizing. ${ }^{3}$ Constrictive bronchiolitis indicates concentric narrowing of the bronchioles by fibrotic changes to the airway wall (Fig. 1). ${ }^{4}$ Proliferative bronchiolitis describes polyps of connective tissue in the bronchiolar lumen. ${ }^{5}$ Bronchiolitis obliterans organizing pneumonia (BOOP) refers to proliferative bronchiolitis with polyps in the alveolar ducts and alveoli and the presence of foamy macrophages in the alveoli (Fig. 2); the idiopathic form of BOOP is termed cryptogenic organizing pneumonia $(C O P){ }^{3}$

Bronchiolitis obliterans and obliterative bronchiolitis have been used clinically and pathologically to describe both constrictive and proliferative bronchiolitis ${ }^{3,5}$; because these terms are imprecise, we specify the histopathology when possible. As we discuss diseases thought to have occupational or environmental causes, we use "BOOP" rather than "COP" for proliferative bronchiolitis with alveolar involvement. Other nonspecific or unique histopathologic patterns are described as such. Although hypersensitivity pneumonitis typically has bronchiolar involvement, its discussion is beyond the scope of this article.

\section{Etiology and Histopathology}

Occupational and environmental causes of bronchiolar disorders are recognized on the basis of case reports, case series, and, less commonly, epidemiologic investigations (Table 1). Oxides of nitrogen, encountered in feed silos, from explosives detonation, or in industrial settings, were some of the first exposures to be associated with bronchiolitis obliterans, specifically proliferative bronchiolitis; proliferative bronchiolitis with features of constrictive bronchiolitis has also been reported. ${ }^{6-12}$ The classic description of this and other irritant gas-related bronchiolitis is of an exposure event leading to acute pulmonary edema, followed by apparent recovery, a latent period lasting weeks, and then onset of progressive dyspnea. ${ }^{7,13-17}$ However, cases of irritant gas-related bronchiolitis in which symptom onset was delayed 10 days to a month after exposure have been reported. ${ }^{15,18-20}$ This delayed presentation raises the possibility of other indolent cases for which an association with an exposure goes unrecognized and the disease is thus considered "idiopathic."

Indeed, the experience with flavoring-related bronchiolitis provides further evidence of indolent exposure-related disease. Two probable cases among flavoring manufacturing workers were investigated in 1985, but a cause could not be identified among the hundreds of ingredients handled. ${ }^{21}$ Later, a cluster of disease occurred among eight former workers of a microwave popcorn production facility who did not report an overexposure event ${ }^{22}$; two of three who underwent lung biopsy had constrictive bronchiolitis. ${ }^{23}$ An epidemiologic evaluation of the current workforce revealed increased rates of respiratory symptoms and airway obstruction in association with cumulative diacetyl exposure, implicating inhalation of this volatile butter flavoring chemical. ${ }^{22}$ Subsequently, cases of histopathologic constrictive bronchiolitis and/or abnormalities on noninvasive testing consistent with bronchiolitis have been documented among flavoring-exposed workers in additional popcorn facilities as well as in other industries, including diacetyl manufacture, flavoring manufacture, cookie production, and coffee roasting. ${ }^{24-27}$ Toxicologic studies have confirmed respiratory epithelial damage in animals exposed to diacetyl and its chemically related substitute, 2,3-pentanedione. ${ }^{28-31}$ 
Two recently reported case series of constrictive bronchiolitis in the fiberglass-reinforced plastics industry highlight the challenges of identifying a causative agent. ${ }^{32,33} \mathrm{~A}$ total of eight cases, four of which were biopsy confirmed, were described among six boat builders, one cooling tower manufacturer, and one water storage tank repairer. Known or probable exposures included resin, styrene, methylethyl ketone peroxide, and dimethyl phthalate. The temporal relationship with employment, occurrence of cases in different workplaces with shared industrial processes, and lack of other known causes of constrictive bronchiolitis suggested an occupational etiology. The unexplained finding of excess mortality from nonmalignant respiratory disease in several epidemiologic studies of similar workforces also provides some corroboration that exposures in this industry may cause constrictive bronchiolitis. ${ }^{32,34}$ Nonetheless, further investigation is needed.

Lung disease related to synthetic fibers was suspected from case reports beginning in 1975, but confirmation required the recognition of case clusters, characterization of workplace exposures, and elimination of other possible causes. ${ }^{35}$ Investigations in the flock industry in the 1990s identified occupational exposure to nylon flock as associated with a unique bronchiolar histopathology, consisting of lymphocytic bronchiolitis and peribronchiolitis with lymphoid hyperplasia represented by lymphoid aggregates and follicles. ${ }^{36-39}$ Flock is a cut fiber of small diameter that is used to produce a velvet-like coating when applied to adhesive-coated fabric or other surfaces, such as automotive glove compartments and jewelry boxes. Nylon respirable dust is generated in the cutting of long filaments into flock, which itself is too large to reach the bronchioles. Although the lymphocytic bronchiolitis is a characteristic distinctive finding, a variety of other histopathologic findings were present in a portion of cases recognized in the setting of case clusters, including acute alveolar damage, BOOP, and increased macrophages with some foci reminiscent of desquamative interstitial pneumonitis. ${ }^{38-40}$ Reports of clinical and epidemiologic evidence of bronchiolar disease in nylon flock workers ${ }^{36,40-42}$ stimulated recognition of clinical and subclinical interstitial lung disease in work settings with other synthetic dusts, including polyethylene flock,

polypropylene flock used in making plastic tows for fishing nets, and rayon flock in greeting card manufacture. ${ }^{43-45}$

Some of what we have learned about exposure-related bronchiolar disorders comes from the experiences of those involved as soldiers or civilians in wars and other conflicts. Case reports of bronchiolitis obliterans (specifically constrictive bronchiolitis) and chronic cellular bronchiolitis in two Iraqi Kurdish victims of chemical weapons attacks ${ }^{46,47}$ have been followed by extensive studies of the more than 30,000 Iranians exposed to sulfur mustard gas during the Iran-Iraq war in the 1980s. Bronchiolar disorders were suspected on the basis of radiologic findings and confirmed by histopathologic studies showing BOOP ( $n$ =9) among 22 transbronchial biopsies and constrictive bronchiolitis $(n=5)$, chronic cellular bronchiolitis $(n=4)$, respiratory bronchiolitis $(n=1)$, follicular bronchiolitis $(n=1)$, and chronic peribronchiolitis $(n=1)$ among 15 surgical biopsies. ${ }^{48-50}$ Notably, there were no histopathologic differences between patients with severe exposures (defined by documented hospitalization at the time of exposure, often with accompanying symptoms such as skin blistering) and those with mild exposures (defined by lack of hospitalization at the time of exposure and the absence of history of acute symptoms such as skin blistering). ${ }^{50}$ 
Bronchiolar disorders have also been noted in relation to the World Trade Center (WTC) disaster. These include a case report of bronchiolitis obliterans (specifically constrictive bronchiolitis) in a police officer who was present at the WTC on September 11, 2001, when the towers collapsed, and two case series demonstrating small airways disease (including chronic inflammation and fibrosis) among a total of 19 responders and community members. ${ }^{51-53}$ Although involvement of the bronchioles in these reported series was near universal, severity varied and the findings rarely met criteria for known histopathologic entities. Analyses of intact and digested lung tissue specimens demonstrated exposure to a variety of minerals (chrysotile asbestos, silica), metals (aluminum, steel, zirconium, chromium, copper, zinc, tin), and carbon nanotubes, the latter presumed to have formed during the disaster as a result of combustion in the presence of carbon and metals. ${ }^{52,53}$ Mineral dust bronchiolitis related to asbestos, silica, iron oxide, aluminum oxide, coal, and other inorganic dusts has been described. ${ }^{54-56}$ Nonetheless, the detection of these materials in lung tissue does not exclude the possible causative role of gaseous exposures that undoubtedly occurred during the WTC collapse, but cannot be reconstructed. Larger retrospective and case-control studies using noninvasive testing have found evidence of small airways dysfunction in WTC-exposed patients with persistent respiratory symptoms, ${ }^{57-60}$ suggesting that the findings in the histopathologic series likely reflect a broader experience of symptomatic exposed workers and residents.

Bronchiolar disorders have been documented in a cohort of U.S. soldiers who served in Iraq and/or Afghanistan. ${ }^{61}$ Of 49 soldiers with exercise intolerance due to exertional dyspnea who underwent lung biopsy, 38 (78\%) were found to have constrictive bronchiolitis. Twenty-eight of these 38 reported exposure to smoke from a sulfur mine fire near Mosul, Iraq, in 2003. Sulfur dioxide levels were reported to be as high as $125 \mathrm{ppm}$. Other common exposures were to dust storms, incinerated solid waste in burn pits, and incinerated human waste. Although a follow-up study did not identify bronchiolitis in a series of returning U.S. soldiers with new onset pulmonary symptoms, that study's protocol did not include lung biopsy, ${ }^{62}$ which was essential to the diagnosis in the earlier series. ${ }^{61}$

Acute and chronic bronchiolar disorders were part of a spectrum of respiratory responses in the Bhopal disaster. On December 3, 1984, large amounts of methyl isocyanate and other poorly characterized chemicals were released into the atmosphere at a Union Carbide pesticide manufacturing plant in Bhopal, India, exposing an estimated 250,000 community members and causing thousands of deaths. ${ }^{63,64}$ Autopsies in those who died in the first days to weeks of exposure showed necrotizing or ulcerative changes of the trachea and major bronchi, areas of necrotizing bronchiolitis, and alveolar changes including septal thickening, hyaline membranes, and emphysematous areas. ${ }^{65}$ Subsequent autopsies in approximately 170 deaths through 1988 provided evidence of progression to interstitial pneumonitis, with increased cellularity and fibrosis; desquamative interstitial pneumonitis, giant cell interstitial pneumonitis, and fibrosing alveolitis patterns were noted. ${ }^{65}$ In some cases, an atypical obliterative bronchiolitis marked by intraluminal and peribronchiolar inflammation was seen. ${ }^{65}$ Although reports of histopathology in more recent autopsies or in symptomatic longterm survivors are lacking, a 1994 random sample of Bhopal residents, stratified by distance of original residence from the pesticide manufacturing plant, documented exposure-related 
dyspnea, cough, and spirometric impairment, consistent with small airways disease due to the gas release 10 years prior. ${ }^{63}$

The Ardystil syndrome, an outbreak of BOOP among textile workers, demonstrates the value of identifying disease etiology for the purposes of prevention. ${ }^{66-69}$ In Spain, three cases of lung disease in young coworkers, including one death, prompted an epidemiologic investigation of eight textile factories where printing dyes were sprayed. ${ }^{67}$ Among a total of 257 workers, $71(28 \%)$ had respiratory abnormalities and $22(9 \%)$ met a radiologic case definition of $\mathrm{BOOP}^{67}$; case series confirmed the histopathology. ${ }^{68,69}$ Clustering of the cases in a short time frame, in two of the factories, and among job titles with direct contact with aerosolized dyes implicated a change in a product used only by those two factories. ${ }^{67}$ Specifically, Acramin FWR, a powder, had been changed to Acramin FWN, a liquid poliamidamine intended to be applied with a brush or sponge rather than by spraying. ${ }^{67-69}$ Ultimately, the outbreak ended after spray printing of textiles was stopped at these factories, but not before a total of six deaths and one lung transplant had occurred. ${ }^{67}$ Subsequently, a smaller outbreak of five cases and one death was reported in Algerian textile workers for whom histopathology was not available. ${ }^{70}$ These workers developed lung disease similar to that described in the Spanish outbreak after Acramin FWN was obtained from the same distributor that supplied one of the Spanish factories. ${ }^{67,70,71}$

Epidemiologic investigation also led to the prevention of an unusual bronchiolar disorder associated with humidifier disinfectant use that was recently described among children and adults in Korea. ${ }^{72,73}$ Pediatric cases were recognized in springtime from2006 to 2011 and adult cases in the spring of $2011 .^{72,74}$ The mortality rate in children was $58 \%(80 / 138)$, while among 17 adults, $53 \%$ died or required lung transplantation. ${ }^{72,74}$ The histopathology had features of constrictive bronchiolitis and BOOP, but was remarkable for evidence of acute injury such as necrotizing bronchiolitis and diffuse alveolar damage. ${ }^{72,74}$ Initial hypotheses about etiology included a novel infectious agent, dust storms, and a genetic disorder, but these were ultimately ruled out. ${ }^{74-76}$ Instead, the seasonality, clustering in families, and occurrence of many cases in peripartum women (who were thought to be more likely to stay inside) led investigators to suspect an environmental exposure in the home. ${ }^{73,74,76}$ Case-control studies demonstrated use of humidifier disinfectants, originally marketed for cleaning a humidifier's water tank but instead used by the public as a water additive to suppress microbial growth, was an independent risk factor for disease in both children and adults. ${ }^{73,76}$ In the 2 years after a national ban on humidifier disinfectants was imposed, no additional cases were detected, providing further evidence for causation. ${ }^{72,73}$ An in vivo study specifically implicated aerosolized polyhexamethylene guanidine, a major ingredient of humidifier disinfectants. ${ }^{77}$

\section{Pathogenesis}

The pathogenesis of most exposure-related bronchiolar diseases is not well characterized. For chemically induced obliterative bronchiolitis, the initial pathologic injury is bronchiolar epithelial damage. ${ }^{78,79}$ Injury may occur on account of strong acids or alkalis, generation of toxic free radicals, ${ }^{55}$ or other agent-specific mechanisms. The subsequent inflammation and fibroproliferative repair response result in fibrosis within the bronchiolar wall in the case of 
constrictive bronchiolitis and fibrosis extending into the bronchiolar lumen, sometimes with alveolar extension, in proliferative bronchiolitis. ${ }^{79}$ Solubility and concentration of the agent, and the duration of the exposure, likely contribute to the type and severity of the lung injury. ${ }^{80}$

Diacetyl and 2,3-pentanedione, which cause indolent onset of constrictive bronchiolitis in flavoring-exposed workers, appear to cause toxicity through three described mechanisms of reactive carbonyl-induced damage. ${ }^{30}$ These mechanisms are modification of essential proteins, interactions with DNA, and reactive oxygen species-induced cell injury. ${ }^{81-85}$ Animal data indicate that protein damage as measured by increased ubiquitination may be a biomarker of diacetyl-induced airway epithelial damage in the mouse. ${ }^{86}$ Ubiquitination is one of many potential responses to damaged protein. ${ }^{86}$ In animal models, diacetyl causes selective lethal toxicity to progenitor Club cells, which play a critical role as airway progenitor cells in humans. ${ }^{87,88}$ Indeed, an animal model of airways fibrosis has been developed in which Club cells are selectively targeted by naphthalene, which is metabolized by cytochrome P-450 monooxygenase system in the Club cells. ${ }^{89}$

For the lymphocytic bronchiolitis and peribronchiolitis of flock worker's lung disease, the pathogenesis is likely very different from chemically induced epithelial damage. In this indolent bronchiolar disease distinct from hypersensitivity pneumonitis, the preponderance of lymphocytes suggests an immune mechanism, consistent with the relapse of workers who returned to the flocking environment. A possible contribution to the pathogenesis is mobilization of iron from endogenous sources around a synthetic fiber, resulting in oxidative stress. ${ }^{90}$

\section{Presentation and Diagnosis}

The symptoms of exposure-related bronchiolar disorders are generally nonspecific respiratory complaints: dyspnea, particularly with exertion; cough; and in some cases, wheeze. ${ }^{80,91}$ Nonetheless, a spectrum of presentations has been reported. Fever may be prominent in cases of proliferative bronchiolitis and BOOP, and also has been reported in some cases of constrictive bronchiolitis and in relation to flock exposure. $7,9,10,23,41,42,69$ Fever was reported in $20 \%$ of adults and $26 \%$ of children with bronchiolar disorders associated with humidifier disinfectant use. ${ }^{72,74}$ Weight loss also has been described. ${ }^{23,37,67}$ With some exposures, mucous membrane or skin irritation occurs $23,46,92$; epistaxis was commonly noted in the Ardystil syndrome. ${ }^{67-69}$ Examination may be entirely normal, or reveal crackles, wheeze, and rarely, clubbing. ${ }^{47,80,91}$

Many case reports and series describe impaired lung function. Reported spirometric abnormalities include obstructive, restrictive, and mixed patterns (Table 2). In cases with low forced vital capacity (FVC) on spirometry, lung volumes may either confirm restriction ${ }^{53,69}$ or provide evidence for obstruction with air trapping. ${ }^{23,93}$ A significant spirometric response to bronchodilators or bronchial hyper-responsiveness on methacholine challenge testing is unusual, but has been reported in some cases. ${ }^{23,37,51,61,69,93}$ Low diffusing capacity also has been noted (Table 2 ). Hypoxemia requiring acute or chronic oxygen therapy has been described. ${ }^{7,37,69,72,74,94}$ On bronchoalveolar lavage, a high 
percentage of lymphocytes $(>25 \%)$ is characteristic of BOOP, while a predominance of eosinophils ( $>10 \%)$ was found in some cases of flock workers' lung disease and humidifier detergent-related lung disease. ${ }^{36,74,91}$

Despite such evidence of abnormal physiology, recent histopathologic series have demonstrated bronchiolar disease in the face of normal lung function. Most cases of sulfur mustard-related bronchiolar disorders had normal spirometry and normal diffusing capacity. ${ }^{49,50}$ The majority (84\%) of returning U.S. soldiers with constrictive bronchiolitis had normal spirometry and approximately $40 \%$ had normal diffusing capacity. ${ }^{61}$ In the Ardystil syndrome, half of the biopsy-confirmed cases of BOOP had normal spirometry and nearly all had normal diffusing capacity at presentation; subsequent falls in FVC and diffusing capacity during treatment occurred. ${ }^{69}$ Thus, normal lung function does not preclude the diagnosis of bronchiolar disorders. Instead, the predominance of lung function abnormalities in some histopathologic series may reflect a clinical bias against the use of biopsy in patients with normal pulmonary physiology. King and colleagues ${ }^{61}$ were criticized for their diagnostic approach to soldiers with exertional dyspnea but normal lung function, and the validity of their histopathologic results was questioned..$^{95,96}$ Yet epidemiologic studies of exposed populations at risk of bronchiolar disorders demonstrate the insensitivity of traditional lung function tests for identifying those with respiratory illness. ${ }^{24,67,97}$

Plain chest radiographs may be normal or show a spectrum of findings from hyperinflation to nodules to reticular infiltrates. ${ }^{5}$ Pneumothorax has been described. ${ }^{23,72}$ Alveolar infiltrates were noted in the Ardystil syndrome, reticulonodular or patchy infiltrates in flock workers' lung disease, and ground glass opacities and consolidation in the Korean outbreak associated with humidifier detergent use. ${ }^{69,72,74,98}$ Tracheal abnormalities, including saber sheath narrowing, have been reported. ${ }^{22,48}$ High-resolution computed tomography (HRCT) offers more detailed information, often identifying abnormalities when the chest radiograph is normal. Several patterns have been described: centrilobular nodules and branching lines (commonly referred to as "tree in bud"); ground glass attenuation or alveolar consolidation; and low attenuation (mosaic perfusion) and air trapping. ${ }^{4,5}$ Dynamic HRCT with expiratory images is more sensitive for detecting mosaic perfusion and air trapping. ${ }^{4}$ Associations between HRCT patterns and histopathology are evident. Centrilobular nodules are typical of cellular bronchiolitis and also can be seen in proliferative bronchiolitis; ground glass attenuation is typical of BOOP; and mosaic perfusion and air trapping are seen in both proliferative and constrictive bronchiolitis. ${ }^{4,91}$

Nonetheless, variations in HRCT findings occur. In one case series of constrictive bronchiolitis, air trapping was a common finding, but ground glass and centrilobular nodules also were seen. ${ }^{93}$ Among six WTC-exposed patients suspected of having interstitial lung disease (rather than small airways disease) on the basis of HRCT findings, five had bronchiolitis or peribronchiolar fibrosis on biopsy. ${ }^{53}$ Multiple cavitary lesions were noted in a case of BOOP associated with exposure to benzalkonium compounds from a cleaning agent. ${ }^{99}$ HRCT features of flock workers' lung disease include ground glass opacities and micronodules, but honeycombing was seen in some cases. ${ }^{98}$ Accompanying abnormalities in the larger airways are notable in some case series of exposure-related bronchiolar disorders, and include bronchial wall thickening; bronchiectasis; and dilated, irregular trachea and 
major airways. ${ }^{23,25,48,53,98}$ Finally, as with lung function, HRCT can be normal despite biopsy-proven bronchiolar disease: most (68\%) returning U.S. soldiers with constrictive bronchiolitis had normal HRCTs. ${ }^{61}$

Given the variable clinical, functional, and radiographic findings in exposure-related bronchiolar disorders, biopsy is warranted for symptoms that remain unexplained after a complete noninvasive evaluation. When a disease cluster is identified, biopsy is also useful in establishing the spectrum of histopathologic abnormalities associated with an exposure. Transbronchial biopsy may be sufficient for some disorders, such as BOOP, if the specimen is large enough to contain all the elements of the lesion and the clinical findings are compatible with the diagnosis. ${ }^{1,100}$ In other disorders, notably constrictive bronchiolitis, the patchy, subtle nature of the histological findings necessitates surgical lung biopsy. ${ }^{100,101}$ Obtaining wedge biopsies from multiple lobes is recommended, as this approach increases the diagnostic yield. ${ }^{100}$ Lesions affecting the bronchioles tend to have a central lobular distribution, and this pattern is often best recognized at low magnification. ${ }^{3}$ However, additional techniques, such as special stains, immunohistochemistry, in situ hybridization, and electron microscopy, are often indicated. ${ }^{3}$ For instance, in advanced constrictive bronchiolitis, completely obliterated bronchioles may not be recognized without elastic stains that identify airway remnants adjacent to small vessels. ${ }^{5}$

\section{Treatment and Clinical Course}

The treatment of exposure-related bronchiolar disorders suffers from a weak, primarily anecdotal, evidence base. In addition to exposure cessation (discussed further later) and supportive measures like supplemental oxygen for hypoxemia and mechanical ventilation for respiratory failure, the most commonly cited therapy is corticosteroids. Inhaled, oral, and parenteral routes of administration have been reported. The use of prednisolone for silo filler's disease was described in a 1956 case series in which the first two patients did not receive corticosteroids and died, while the second two received prednisolone or prednisone and had dramatic symptomatic improvement within 12 to 24 hours, followed by incomplete radiographic resolution over several months. ${ }^{7}$ Other publications on silo filler's disease either describe robust responses to corticosteroids or attribute an observed lack of bronchiolitis following nitrous oxide exposure to early use of corticosteroids. ${ }^{9-11,15,18,19,92}$ One of the two sisters who were exposed to chlorine gas in their home was treated with hydrocortisone and prednisone and had a complete recovery, while the other did not receive corticosteroids and had chronic dyspnea and reduced lung function more than 4 years later. ${ }^{102}$

Unfortunately, such a therapeutic benefit of corticosteroids appears to be unusual. A lack of response to corticosteroids is characteristic of bronchiolar disorders related to diacetyl, sulfur mustard, the WTC disaster, and humidifier disinfectant use. ${ }^{23,50,51,72,74}$ Corticosteroids appeared to prevent disease progression in one patient exposed to thionylchloride but not in the other patient, who required prolonged critical care. ${ }^{20}$ Idiopathic BOOP (COP) is usually responsive to corticosteroids, with a cure rate of $80 \% .{ }^{91,103}$ The case of benzalkonium compounds-associated BOOP promptly resolved with prednisone. ${ }^{99}$ Nonetheless, among 14 textile workers with Ardystil syndrome, 
corticosteroids did not prevent initial progression in 11 or development of irreversible respiratory failure in $5 .{ }^{69}$ Introduction of corticosteroids at an earlier stage, when lung function was relatively more preserved, was associated with better outcomes. ${ }^{69}$ In a case of BOOP in a potato chip factory worker who handled seasonings, use of oral corticosteroids for 2 years resulted in an unfavorable but "stable" condition, characterized by disability and a requirement for supplemental oxygen. ${ }^{94}$ Other immunomodulatory drugs, including cyclophosphamide, hydroxychloroquine, and intravenous immunoglobulin, have been tried in some cases, without clear benefit. $23,69,72,74$

There is limited experience with other pharmacotherapies. Inhaled bronchodilators have been described as ineffective in many reports. ${ }^{22,36,37,47,50}$ However, as noted earlier, a bronchodilator response was documented in a minority of cases of exposure-related constrictive bronchiolitis, the Ardystil syndrome, and flock workers' lung disease, ${ }^{23,37,61,69,93}$ suggesting bronchodilators may be useful in select patients. Bronchodilators appeared to benefit one WTC-exposed patient (with restrictive spirometry, mosaic attenuation on HRCT, and chronic bronchiolitis, bronchiolar fibrosis, and emphysema on histopathology) who did not respond to oral corticosteroids but experienced a marked reduction in lung volumes when inhaled corticosteroids and bronchodilators were discontinued. ${ }^{53}$ Macrolide antibiotics are effective in the idiopathic bronchiolar disorder diffuse panbronchiolitis and have shown some promise for idiopathic BOOP (COP) and early transplant-associated bronchiolitis obliterans syndrome, presumably due to antiinflammatory effects. ${ }^{104}$ Nonetheless, their use for exposure-related bronchiolar disorders has been infrequently described. In one case series of sulfur mustard-related disease, symptom progression despite macrolide therapy was noted ${ }^{50}$ In the case of constrictive bronchiolitis in a WTC-exposed police officer, azithromycin was associated with substantial $(>2 \mathrm{~L})$ increases in FVC and forced expiratory volume in one second $\left(\mathrm{FEV}_{1}\right)$, although dyspnea persisted. ${ }^{51}$ Oral $\mathrm{N}$-acetylcysteine therapy resulted in reduced respiratory symptoms and improved pulmonary function compared with placebo in two small clinical trials involving Iranian sulfur mustard-exposed patients. ${ }^{105}$

Lung transplantation for exposure-related bronchiolar disorders has been reported occasionally. The first international alert on the Ardystil syndrome came in 1993 and noted that lung donors were needed to provide transplants for over 10 workers poisoned by paint fumes. ${ }^{71}$ One double lung transplantation was subsequently reported, with a good outcome at 33 months of follow-up. ${ }^{67,69}$ In the Korean humidifier disinfectant outbreak, four adults and one child underwent lung transplantation. ${ }^{72,74}$ For the adult patients, transplantations occurred in 2011 and all were alive as of the 2014 report; details on the pediatric transplantation were not provided. ${ }^{72,74}$ Two of the cases of constrictive bronchiolitis in the fiberglass-reinforced plastics industry underwent heart-lung or lung transplantation and experienced long-term survival: one died of complications more than 20 years later, while the other was alive at approximately 15 years of follow-up. ${ }^{32}$ Five microwave popcorn workers were on waiting lists in $2004,{ }^{23}$ but to date none has undergone transplantation. An outbreak in Taiwan of constrictive bronchiolitis related to consumption of juice made from the Sauropus androgynus vegetable leaf led to single lung transplantation in eight patients; 
progressive deterioration within a year was thought due to bronchiolitis obliterans syndrome in the transplanted lung. 106

For ongoing exposures, exposure cessation is a mainstay of treatment. One fiberglassreinforced plastics industry worker whose clinical presentation was consistent with constrictive bronchiolitis reportedly improved away from work, although he remained disabled. ${ }^{32}$ Patients with flock workers' lung disease who continued to work in the flock plant experienced no improvement or worsening of their condition despite corticosteroid therapy; those who left the workplace had symptomatic, functional, and radiographic improvement even without medication. ${ }^{36,37}$ Furthermore, those who improved and attempted to return to the workplace had subjective and objective relapses. ${ }^{37}$ In the Ardystil syndrome, epistaxis resolved quickly following removal from exposure, and all surviving patients had normalization of pulmonary function within 4 years of leaving the workplace. ${ }^{69}$ In the series of nine former microwave popcorn workers, seven experienced improvement in cough — though not dyspnea — and stabilization of lung function after leaving employment. ${ }^{23}$ After controls to reduce diacetyl exposures were introduced at the plant, current workers had normalization of their mean annualized $\mathrm{FEV}_{1}$ decline, from about -140 $\mathrm{mL} /$ year to $-20 \mathrm{~mL} /$ year. ${ }^{107}$ Notably, this pattern has also been seen after short-term accidental exposures. Reports of chlorine gas exposure documented excessive declines in spirometric parameters during the first 2 years postexposure, after which rates of decline normalized. ${ }^{102,108}$ Patients suspected of having bronchiolar disease after exposure to ammonia had gradual deterioration of pulmonary function over the initial 2 to 6 months, followed by slight improvement and then stabilization with no subsequent change over a 2year follow-up. ${ }^{109}$ Emergency responders following the WTC disaster had large declines in $\mathrm{FEV}_{1}$ in the year following exposure that persisted without recovery or further excessive decline over the next 6 years. ${ }^{110}$ Notably, stabilization after exposure cessation is in contrast to the inexorable downhill course of bronchiolitis obliterans syndrome in transplant recipients. ${ }^{101}$

The long-term outcome of exposure-related bronchiolar disorders is often poor, although recovery from some exposures has been described. Apart from acute deaths due to pulmonary edema and deaths from proliferative bronchiolitis in the era before corticosteroid use, most cases of silo filler's disease are described as recovering and being asymptomatic on follow-up, albeit some with residual functional and radiographic abnormalities. $^{7,9-11,13,18,19}$ Chronic respiratory symptoms, lung function impairment, and excess respiratory disease mortality have been documented in diacetyl-exposed workers. ${ }^{22,23,111,112}$ Three of six cases of constrictive bronchiolitis in the fiberglassreinforced plastics industry died from respiratory disease or underwent lung transplantation, while the survivors had significant respiratory morbidity. ${ }^{32}$ A 20 -year follow-up of nine cases of nylon flock workers' lung disease demonstrated complete resolution in five and persistent lung disease in four, including two who progressed to hypoxemic respiratory failure and death 18 and 20 years after initial presentation. ${ }^{113}$ Progressive disease was also described in a case of polyethylene flock worker's lung disease. ${ }^{43}$ An increased risk of lung cancer in flock workers has also been described. ${ }^{114}$ Fifteen years after exposure, sulfur mustard-exposed patients with bronchiolar disorders continued to have cough and dyspnea. ${ }^{49,50}$ Chronic respiratory symptoms, persistent but stable restrictive lung 
physiology, and hypoxemia necessitating supplemental oxygen therapy were characteristic of WTC-exposed patients 4 to 6 years after the disaster. ${ }^{53}$ One to 6 years after the diagnosis of constrictive bronchiolitis in returning U.S. soldiers, half had left the service with a disability rating and more than half reported dyspnea on exertion and limited job opportunities due to respiratory impairment. ${ }^{61}$ Ten years after the Bhopal disaster, interviews with exposed community members revealed high prevalences of cough (54\%) and dyspnea (84\%); those reporting symptoms had reduced lung function. ${ }^{63}$ Although the Ardystil syndrome and the lung disease associated with humidifier disinfectant use had high short-term mortality, survivors were noted to have favorable, often complete, recovery during relatively short (maximum 5 years') follow-up periods. ${ }^{69,72,115}$

\section{Research Needs}

A recurrent theme of this review is that the distinctions among types of bronchiolar disorders - in physiology, radiography, histopathology, and natural history - are not clearcut in the investigation of populations with a single causal exposure. In the past, individual cases of occupational or environmental bronchiolar disease were recognized following acute onset after accidental overexposures. Cases without objective functional and radiographic abnormalities, or those lacking a dramatic event or with delayed or indolent onset, may not have prompted consideration of a bronchiolar disorder in the differential diagnosis or an exposure as a possible etiology. Thus, the "classic" textbook descriptions of bronchiolar disorders suffer from the stereotypes that enabled their recognition, but should not be used to exclude consideration of the diagnosis in individuals who do not fall neatly into one category.

The indolent onset forms now being recognized as having occupational causes, such as flavoring-related constrictive bronchiolitis, were investigated because of severe disease clusters in defined workforces or industries. With sentinel cases prompting an investigation of coworkers, the evidence of bronchiolar disease broadened to a spectrum of spirometric indices, radiographic findings, and subclinical abnormalities. The disease spectrum requires further research, as many of the epidemiologic investigations in the last decade, for example in flavorings, concentrated on fixed obstructive disease. ${ }^{22,25}$ Recent recognition of pathologic constrictive bronchiolitis with normal or restrictive spirometry requires reevaluation of earlier and future data with definitions that include exertional dyspnea, recognizing that objective tests for identifying small airways disease are limited. In every population-based investigation following sentinel cases, evidence of subclinical or undiagnosed cases has been found. Examples include flavoring-related lung disease in microwave popcorn, diacetyl, and flavoring manufacturing; WTC responders; methyl isocyanate exposure in Bhopal; dye-exposed workers in Ardystil; and flock-exposed workers with several synthetic fibers. ${ }^{22,41,44,45,63,67,97,110,111}$ Follow-up of sentinel cases by epidemiologically examining the exposed population from which they came will generate the knowledge about risk factors and causes that allow prevention of additional cases.

Another need is for the development of better diagnostic and screening methods for small airways disease. Traditional tests such as spirometry have been shown to be insensitive for identifying bronchiolar disorders. A nontraditional test, impulse oscillometry, has been used 
in studies of WTC-exposed subjects with persistent respiratory symptoms, and appears to be more sensitive than spirometry for distal airways disease in this setting. ${ }^{59,60,116}$ The performance of impulse oscillometry in other exposed populations at risk for bronchiolar disorders needs evaluation. Few biomarkers have been identified for exposure-related bronchiolar disorders. Biomarkers that have been explored in transplant-related bronchiolitis obliterans syndrome and idiopathic pulmonary fibrosis, including hyaluronan, amphiregulin, club cell secretory protein, and interleukin-8, ${ }^{117-120}$ may have utility for early identification of exposure-related bronchiolar disorders, and also could expand our limited understanding of pathogenesis.

Few treatments for exposure-related bronchiolar disorders have been subjected to formal clinical evaluation. Questions regarding choice of drugs (such as corticosteroids, antiinflammatories, and cytotoxic agents), dosing, optimal timing of initiation following exposure, and duration of therapy have not been addressed. Since bronchiolar diseases are rare, the best opportunity for randomized clinical trials would be in the setting of disasters, such as occurred in Bhopal in 1984 or at the WTC in 2001. Perhaps there is a role of government to prepare predisaster institutional review board approval for clinical trials pertinent to potential exposure to agents known to cause bronchiolar disorders, such as from train derailments, wartime exposures, or terrorist events. Otherwise, emergency care of casualties will remain a trial of corticosteroids with little evidence for their efficacy, particularly for constrictive bronchiolitis. Other modalities for treatment, such as whole lung lavage, could also be subjected to randomized clinical trial.

Several new causes of obliterative bronchiolitis have been identified when chemicals or processes were changed without considering the possible human health impact. In microwave popcorn manufacture, the diacetyl content of artificial butter flavoring was increased when low-fat popcorn began to be manufactured. ${ }^{121}$ In the Ardystil syndrome, a textile dye that had not been recognized as causing occupational lung disease began to be sprayed instead of applied by sponges. ${ }^{67-69}$ In Korea, chemicals manufactured for the cleaning of humidifiers were used by consumers as an additive to humidification water, resulting in an aerosol exposure that was not anticipated. ${ }^{73}$ When an environmental or occupational cause is suspected, exploration of changes in process or content are often helpful. Premarket inhalation toxicology evaluation is not a regulatory requirement, resulting in the potential for occupational or environmental lung disease in workers and the general public who inhale agents with unanticipated pulmonary toxicity. ${ }^{121}$

\section{Acknowledgments}

This work was supported by intramural funding from the National Institute for Occupational Safety and Health (NIOSH). The findings and conclusions in this report are those of the authors and do not necessarily represent the views of NIOSH. The authors thank Dr. Ann Hubbs and Tia McClelland of NIOSH and Dr. Victor Roggli and Steven Conlon of Duke University School of Medicine for their invaluable contributions.

\section{References}

1. Ryu JH, Myers JL, Swensen SJ. Bronchiolar disorders. Am J Respir Crit Care Med. 2003; 168(11): 1277-1292. [PubMed: 14644923] 
2. Visscher DW, Myers JL. Bronchiolitis: the pathologist's perspective. Proc Am Thorac Soc. 2006; 3(1):41-47. [PubMed: 16493150]

3. Couture C, Colby TV. Histopathology of bronchiolar disorders. Semin Respir Crit Care Med. 2003; 24(5):489-498. [PubMed: 16088569]

4. Poletti V, Costabel U. Bronchiolar disorders: classification and diagnostic approach. Semin Respir Crit Care Med. 2003; 24(5):457-464. [PubMed: 16088566]

5. Timens, W.; Sietsma, H.; Wright, JL. Chronic obstructive pulmonary disease and diseases of the airways. In: Hastleton, P.; Flieder, DB., editors. Spenser's Pathology of the Lung. 6th ed.. Cambridge: Cambridge University Press; 2013. p. 605-660.

6. Fraenkel A. Ueber bronchiolitis fibrosa oliterans, nebst bemerkungen ber lungenhyperämie und indurierende pneumonia. Dtsch Arch Klin Med. 1902; 73:484-510.

7. Lowry T, Schuman LM. Silo-filler's disease: a syndrome caused by nitrogen dioxide. J Am Med Assoc. 1956; 162(3):153-160. [PubMed: 13357306]

8. Darke CS, Warrack AJ. Bronchiolitis from nitrous fumes. Thorax. 1958; 13(4):327-333. [PubMed: 13625233]

9. Moskowitz RL, Lyons HA, Cottle HR. Silo filler's disease: clinical, physiologic and pathologic study of a patient. Am J Med. 1964; 36:457-462.

10. Horvath EP, doPico GA, Barbee RA, Dickie HA. Nitrogen dioxide-induced pulmonary disease: five new cases and a review of the literature. J Occup Med. 1978; 20(2):103-110. [PubMed: 627925]

11. Fleetham JA, Munt PW, Tunnicliffe BW. Silo-filler's disease. Can Med Assoc J. 1978; 119(5): 482-484. [PubMed: 688149]

12. Epler GR. Silo-filler's disease: a new perspective. Mayo Clin Proc. 1989; 64(3):368-370. [PubMed: 2704256]

13. Becklake MR, Goldman HI, Bosman AR, Freed CC. The long-term effects of exposure to nitrous fumes. Am Rev Tuberc. 1957; 76(3):398-409. [PubMed: 13458722]

14. Milne JE. Nitrogen dioxide inhalation and bronchiolitis obliterans. A review of the literature and report of a case. J Occup Med. 1969; 11(10):538-547. [PubMed: 5823692]

15. Tse RL, Bockman AA. Nitrogen dioxide toxicity. Report of four cases in firemen. JAMA. 1970; 212(8):1341-1344. [PubMed: 4910819]

16. Woodford DM, Coutu RE, Gaensler EA. Obstructive lung disease from acute sulfur dioxide exposure. Respiration. 1979; 38(4):238-245. [PubMed: 523832]

17. Kraut A, Lilis R. Chemical pneumonitis due to exposure to bromine compounds. Chest. 1988; 94(1):208-210. [PubMed: 3383640]

18. Ramirez J, Dowell AR. Silo-filler's disease: nitrogen dioxide-induced lung injury. Long-term follow-up and review of the literature. Ann Intern Med. 1971; 74(4):569-576. [PubMed: 5573158]

19. Zwemer FL Jr, Pratt DS, May JJ. Silo filler's disease in New York State. Am Rev Respir Dis. 1992; 146(3):650-653. [PubMed: 1519842]

20. Konichezky S, Schattner A, Ezri T, Bokenboim P, Geva D. Thionylchloride-induced lung injury and bronchiolitis obliterans. Chest. 1993; 104(3):971-973. [PubMed: 8365329]

21. McConnell, R.; Hartle, RW. Health hazard evaluation report: International Bakers Services, Inc., South Bend, Indiana. Cincinnati, OH: U.S. Department of Health and Human Services, Centers for Disease Control and Prevention, National Institute for Occupational Safety and Health (NIOSH); 1986. HETA Report No. 1985-171-1710.

22. Kreiss K, Gomaa A, Kullman G, Fedan K, Simoes EJ, Enright PL. Clinical bronchiolitis obliterans in workers at a microwave-popcorn plant. N Engl J Med. 2002; 347(5):330-338. [PubMed: 12151470]

23. Akpinar-Elci M, Travis WD, Lynch DA, Kreiss K. Bronchiolitis obliterans syndrome in popcorn production plant workers. Eur Respir J. 2004; 24(2):298-302. [PubMed: 15332401]

24. Kanwal R, Kullman G, Piacitelli C, et al. Evaluation of flavorings-related lung disease risk at six microwave popcorn plants. J Occup Environ Med. 2006; 48(2):149-157. [PubMed: 16474263] 
25. van Rooy FG, Rooyackers JM, Prokop M, Houba R, Smit LA, Heederik DJ. Bronchiolitis obliterans syndrome in chemical workers producing diacetyl for food flavorings. Am J Respir Crit Care Med. 2007; 176(5):498-504. [PubMed: 17541015]

26. Cavalcanti, ZdoR; Albuquerque Filho, AP.; Pereira, CA.; Coletta, EN. Bronchiolitis associated with exposure to artificial butter flavoring in workers at a cookie factory in Brazil. J Bras Pneumol. 2012; 38(3):395-399. [PubMed: 22782611]

27. Centers for Disease Control and Prevention (CDC). Obliterative bronchiolitis in workers in a coffee-processing facility - Texas, 2008-2012. MMWR Morb Mortal Wkly Rep. 2013; 62(16): 305-307. [PubMed: 23615673]

28. Hubbs AF, Goldsmith WT, Kashon ML, et al. Respiratory toxicologic pathology of inhaled diacetyl in Sprague-Dawley rats. Toxicol Pathol. 2008; 36(2):330-344. [PubMed: 18474946]

29. Morgan DL, Flake GP, Kirby PJ, Palmer SM. Respiratory toxicity of diacetyl in C57BL/6 mice. Toxicol Sci. 2008; 103(1):169-180. [PubMed: 18227102]

30. Hubbs AF, Cumpston AM, Goldsmith WT, et al. Respiratory and olfactory cytotoxicity of inhaled 2,3-pentanedione in Sprague-Dawley rats. Am J Pathol. 2012; 181(3):829-844. [PubMed: 22894831]

31. Morgan DL, Jokinen MP, Price HC, Gwinn WM, Palmer SM, Flake GP. Bronchial and bronchiolar fibrosis in rats exposed to 2,3-pentanedione vapors: implications for bronchiolitis obliterans in humans. Toxicol Pathol. 2012; 40(3):448-465. [PubMed: 22215510]

32. Cullinan P, McGavin CR, Kreiss K, et al. Obliterative bronchiolitis in fibreglass workers: a new occupational disease? Occup Environ Med. 2013; 70(5):357-359. [PubMed: 23322914]

33. Chen CH, Tsai PJ, Wang WC, Pan CH, Ho JJ, Guo YL. Obliterative bronchiolitis in workers laying up fiberglass-reinforced plastics with polyester resin and methylethyl ketone peroxide catalyst. Occup Environ Med. 2013; 70(9):675-676. [PubMed: 23739490]

34. Cummings KJ, McCague AB, Kreiss K. Nonmalignant respiratory disease mortality in styreneexposed workers. Epidemiology. 2014; 25(1):160-161. [PubMed: 24296936]

35. Kreiss K. Occupational lung disease: from case reports to prevention. Chest. 2013; 143(6):15291531. [PubMed: 23732577]

36. Kern DG, Crausman RS, Durand KT, Nayer A, Kuhn C III. Flock worker's lung: chronic interstitial lung disease in the nylon flocking industry. Ann Intern Med. 1998; 129(4):261-272. [PubMed: 9729178]

37. Eschenbacher WL, Kreiss K, Lougheed MD, Pransky GS, Day B, Castellan RM. Nylon flockassociated interstitial lung disease. Am J Respir Crit Care Med. 1999; 159(6):2003-2008. [PubMed: 10351952]

38. Boag AH, Colby TV, Fraire AE, et al. The pathology of interstitial lung disease in nylon flock workers. Am J Surg Pathol. 1999; 23(12):1539-1545. [PubMed: 10584708]

39. Kern DG, Kuhn C III, Ely EW, et al. Flock worker's lung: broadening the spectrum of clinicopathology, narrowing the spectrum of suspected etiologies. Chest. 2000; 117(1):251-259. [PubMed: 10631226]

40. Lougheed MD, Roos JO, Waddell WR, Munt PW. Desquamative interstitial pneumonitis and diffuse alveolar damage in textile workers. Potential role of mycotoxins. Chest. 1995; 108(5): 1196-1200. [PubMed: 7587416]

41. Washko RM, Day B, Parker JE, Castellan RM, Kreiss K. Epidemiologic investigation of respiratory morbidity at a nylon flock plant. Am J Ind Med. 2000; 38(6):628-638. [PubMed: 11071685]

42. Daroowalla F, Wang M-L, Piacitelli C, Attfield MD, Kreiss K. Flock workers' exposures and respiratory symptoms in five plants. Am J Ind Med. 2005; 47(2):144-152. [PubMed: 15662645]

43. Barroso E, Ibañez MD, Aranda FI, Romero S. Polyethylene flock-associated interstitial lung disease in a Spanish female. Eur Respir J. 2002; 20(6):1610-1612. [PubMed: 12503723]

44. Atis S, Tutluoglu B, Levent E, et al. The respiratory effects of occupational polypropylene flock exposure. Eur Respir J. 2005; 25(1):110-117. [PubMed: 15640331]

45. Antao VC, Piacitelli CA, Miller WE, Pinheiro GA, Kreiss K. Rayon flock: a new cause of respiratory morbidity in a card processing plant. Am J Ind Med. 2007; 50(4):274-284. [PubMed: 17370318] 
46. Thomason JW, Rice TW, Milstone AP. Bronchiolitis obliterans in a survivor of a chemical weapons attack. JAMA. 2003; 290(5):598-599. [PubMed: 12902361]

47. Dompeling E, Jöbsis Q, Vandevijver NM, Wesseling G, Hendriks H. Chronic bronchiolitis in a 5yr-old child after exposure to sulphur mustard gas. Eur Respir J. 2004; 23(2):343-346. [PubMed: 14979514]

48. Ghanei M, Mokhtari M, Mohammad MM, Aslani J. Bronchiolitis obliterans following exposure to sulfur mustard: chest high resolution computed tomography. Eur J Radiol. 2004; 52(2):164-169. [PubMed: 15489074]

49. Beheshti J, Mark EJ, Akbaei HM, Aslani J, Ghanei M. Mustard lung secrets: long term clinicopathological study following mustard gas exposure. Pathol Res Pract. 2006; 202(10):739_ 744. [PubMed: 16887283]

50. Ghanei M, Tazelaar HD, Chilosi M, et al. An international collaborative pathologic study of surgical lung biopsies from mustard gas-exposed patients. Respir Med. 2008; 102(6):825-830. [PubMed: 18339530]

51. Mann JM, Sha KK, Kline G, Breuer FU, Miller A. World Trade Center dyspnea: bronchiolitis obliterans with functional improvement: a case report. Am J Ind Med. 2005; 48(3):225-229. [PubMed: 16094618]

52. Wu M, Gordon RE, Herbert R, et al. Case report: Lung disease in World Trade Center responders exposed to dust and smoke: carbon nanotubes found in the lungs of World Trade Center patients and dust samples. Environ Health Perspect. 2010; 118(4):499-504. [PubMed: 20368128]

53. Caplan-Shaw CE, Yee H, Rogers L, et al. Lung pathologic findings in a local residential and working community exposed to World Trade Center dust, gas, and fumes. J Occup Environ Med. 2011; 53(9):981-991. [PubMed: 21860325]

54. Wright JL, Cagle P, Churg A, Colby TV, Myers J. Diseases of the small airways. Am Rev Respir Dis. 1992; 146(1):240-262. [PubMed: 1626808]

55. Seaton, A. Bronchiolar disease. In: Seaton, A.; Seaton, D.; Leitch, AG., editors. Crofton and Douglas's Respiratory Disease. 5th ed.. London: Wiley Inc.; 2008. p. 829-838.

56. Stansbury RC, Beeckman-Wagner LA, Wang ML, Hogg JP, Petsonk EL. Rapid decline in lung function in coal miners: evidence of disease in small airways. Am J Ind Med. 2013; 56(9):11071112. [PubMed: 23737372]

57. Mendelson DS, Roggeveen M, Levin SM, Herbert R, de la Hoz RE. Air trapping detected on endexpiratory high-resolution computed tomography in symptomatic World Trade Center rescue and recovery workers. J Occup Environ Med. 2007; 49(8):840-845. [PubMed: 17693781]

58. Weiden MD, Ferrier N, Nolan A, et al. Obstructive airways disease with air trapping among firefighters exposed to World Trade Center dust. Chest. 2010; 137(3):566-574. [PubMed: 19820077]

59. Friedman SM, Maslow CB, Reibman J, et al. Case-control study of lung function in World Trade Center Health Registry area residents and workers. Am J Respir Crit Care Med. 2011; 184(5):582589. [PubMed: 21642248]

60. Berger KI, Reibman J, Oppenheimer BW, Vlahos I, Harrison D, Goldring RM. Lessons from the World Trade Center disaster: airway disease presenting as restrictive dysfunction. Chest. 2013; 144(1):249-257. [PubMed: 23392588]

61. King MS, Eisenberg R, Newman JH, et al. Constrictive bronchiolitis in soldiers returning from Iraq and Afghanistan. N Engl J Med. 2011; 365(3):222-230. [PubMed: 21774710]

62. Morris MJ, Dodson DW, Lucero PF, et al. Study of active duty military for pulmonary disease related to environmental deployment exposures (STAMPEDE). Am J Respir Crit Care Med. 2014; 190(1):77-84. [PubMed: 24922562]

63. Cullinan P, Acquilla S, Dhara VR. The International Medical Commission on Bhopal. Respiratory morbidity 10 years after the Union Carbide gas leak at Bhopal: a cross sectional survey. BMJ. 1997; 314(7077):338-342. [PubMed: 9040323]

64. Dhara VR, Gassert TH. The Bhopal syndrome: persistent questions about acute toxicity and management of gas victims. Int J Occup Environ Health. 2002; 8(4):380-386. [PubMed: 12412857]

65. Sriramachari S. The Bhopal gas tragedy: an environmental disaster. Curr Sci. 2004; 86:905-920. 
66. Sanz P, Prat A. Toxicity in textile air-brushing in Spain. Lancet. 1993; 342(8865):240. [PubMed: 8100958]

67. Moya C, Antó JM, Taylor AJ. Collaborative Group for the Study of Toxicity in Textile Aerographic Factories. Outbreak of organising pneumonia in textile printing sprayers. Lancet. 1994; 344(8921):498-502. [PubMed: 7914612]

68. Solé A, Cordero PJ, Morales P, Martínez ME, Vera F, Moya C. Epidemic outbreak of interstitial lung disease in aerographics textile workers—-the "Ardystil syndrome": a first year follow up. Thorax. 1996; 51(1):94-95. [PubMed: 8658381]

69. Romero S, Hernández L, Gil J, Aranda I, Martín C, Sanchez-Payá J. Organizing pneumonia in textile printing workers: a clinical description. Eur Respir J. 1998; 11(2):265-271. [PubMed: 9551723]

70. Ould Kadi F, Mohammed-Brahim B, Fyad A, Lellou S, Nemery B. Outbreak of pulmonary disease in textile dye sprayers in Algeria. Lancet. 1994; 344(8927):962-963. [PubMed: 7934379]

71. Camus P, Nemery B. A novel cause for bronchiolitis obliterans organizing pneumonia: exposure to paint aerosols in textile workshops. Eur Respir J. 1998; 11(2):259-262. [PubMed: 9551721]

72. Kim KW, Ahn K, Yang HJ, et al. Humidifier disinfectant-associated children's interstitial lung disease. Am J Respir Crit Care Med. 2014; 189(1):48-56. [PubMed: 24199596]

73. Kim HJ, Lee MS, Hong SB, et al. A cluster of lung injury cases associated with home humidifier use: an epidemiological investigation. Thorax. 2014; 69(8):703-708. [PubMed: 24488371]

74. Hong SB, Kim HJ, Huh JW, et al. Korean Unknown Severe Respiratory Failure Collaborative. Korean Study Group of Respiratory Failure. A cluster of lung injury associated with home humidifier use: clinical, radiological and pathological description of a new syndrome. Thorax. 2014; 69(8):694-702. [PubMed: 24473332]

75. Lee E, Seo JH, Kim HY, et al. Two series of familial cases with unclassified interstitial pneumonia with fibrosis. Allergy Asthma Immunol Res. 2012; 4(4):240-244. [PubMed: 22754718]

76. Yang HJ, Kim HJ, Yu J, et al. Inhalation toxicity of humidifier disinfectants as a risk factor of children's interstitial lung disease in Korea: a case-control study. PLoS ONE. 2013; 8(6):e64430. [PubMed: 23755124]

77. Park S, Lee K, Lee EJ, et al. Humidifier disinfectant-associated interstitial lung disease in an animal model induced by polyhexamethylene guanidine aerosol. Am J Respir Crit Care Med. 2014; 190(6):706-708. [PubMed: 25221883]

78. King TE Jr. Bronchiolitis obliterans. Lung. 1989; 167(2):69-93. [PubMed: 2494394]

79. Barker AF, Bergeron A, Rom WN, Hertz MI. Obliterative bronchiolitis. N Engl J Med. 2014; 370(19):1820-1828. [PubMed: 24806161]

80. King TE Jr. Miscellaneous causes of bronchiolitis: inhalational, infectious, drug-induced, and idiopathic. Semin Respir Crit Care Med. 2003; 24(5):567-576. [PubMed: 16088573]

81. Mathews JM, Watson SL, Snyder RW, Burgess JP, Morgan DL. Reaction of the butter flavorant diacetyl (2,3-butanedione) with $\mathrm{N}$-a-acetylarginine: a model for epitope formation with pulmonary proteins in the etiology of obliterative bronchiolitis. J Agric Food Chem. 2010; 58(24):1276112768. [PubMed: 21077678]

82. More SS, Raza A, Vince R. The butter flavorant, diacetyl, forms a covalent adduct with 2deoxyguanosine, uncoils DNA, and leads to cell death. J Agric Food Chem. 2012; 60(12):33113317. [PubMed: 22385266]

83. Amicarelli F, Colafarina S, Cattani F, et al. Scavenging system efficiency is crucial for cell resistance to ROS-mediated methylglyoxal injury. Free Radic Biol Med. 2003; 35(8):856-871. [PubMed: 14556850]

84. Matsunaga T, Kamiya T, Sumi D, Kumagai Y, Kalyanaraman B, Hara A. L-Xylulose reductase is involved in 9,10-phenanthrenequinone-induced apoptosis in human T lymphoma cells. Free Radic Biol Med. 2008; 44(6):1191-1202. [PubMed: 18206670]

85. Brouwers O, Niessen PM, Haenen G, et al. Hyperglycaemia-induced impairment of endotheliumdependent vasorelaxation in rat mesenteric arteries is mediated by intracellular methylglyoxal levels in a pathway dependent on oxidative stress. Diabetologia. 2010; 53(5):989-1000. [PubMed: 20186387] 
86. Hubbs AF, Fluharty KL, Goravanahally MP, et al. Diacetyl-induced respiratory and olfactory toxicity in mice: Influence of ubiquitination, gender, and dicarbonyl/L-xylulose reductase gene knockout. Toxicologist. 2013; 132(1):237.

87. Palmer SM, Flake GP, Kelly FL, et al. Severe airway epithelial injury, aberrant repair and bronchiolitis obliterans develops after diacetyl instillation in rats. PLoS ONE. 2011; 6(3):e17644. [PubMed: 21464978]

88. Kelly FL, Kennedy VE, Jain R, et al. Epithelial clara cell injury occurs in bronchiolitis obliterans syndrome after human lung transplantation. Am J Transplant. 2012; 12(11):3076-3084. [PubMed: 22883104]

89. Aoshiba K, Tsuji T, Itoh M, et al. A murine model of airway fibrosis induced by repeated naphthalene exposure. Exp Toxicol Pathol. 2014; 66(4):169-177. [PubMed: 24480153]

90. Ghio AJ, Funkhouser W, Pugh CB, et al. Pulmonary fibrosis and ferruginous bodies associated with exposure to synthetic fibers. Toxicol Pathol. 2006; 34(6):723-729. [PubMed: 17074740]

91. Epler GR. Bronchiolitis obliterans organizing pneumonia, 25 years: a variety of causes, but what are the treatment options? Expert Rev Respir Med. 2011; 5(3):353-361. [PubMed: 21702658]

92. Douglas WW, Hepper NG, Colby TV. Silo-filler's disease. Mayo Clin Proc. 1989; 64(3):291-304. [PubMed: 2704252]

93. Markopoulo KD, Cool CD, Elliot TL, et al. Obliterative bronchiolitis: varying presentations and clinicopathological correlation. Eur Respir J. 2002; 19(1):20-30. [PubMed: 11843321]

94. Alleman T, Darcey DJ. Case report: bronchiolitis obliterans organizing pneumonia in a spice process technician. J Occup Environ Med. 2002; 44(3):215-216. [PubMed: 11911018]

95. Morris MJ, Zacher LL. Constrictive bronchiolitis in soldiers. N Engl J Med. 2011; 365(18):17431744. author reply 1744-1745. [PubMed: 22047575]

96. Kuschner WG. Constrictive bronchiolitis in soldiers. N Engl J Med. 2011; 365(18):1744. author reply 1744-1745. [PubMed: 22047576]

97. Cummings KJ, Boylstein RJ, Stanton ML, et al. Respiratory symptoms and lung function abnormalities related to work at a flavouring manufacturing facility. Occup Environ Med. 2014; 71(8):549-554. [PubMed: 24891557]

98. Weiland DA, Lynch DA, Jensen SP, et al. Thin-section CT findings in flock worker's lung, a work-related interstitial lung disease. Radiology. 2003; 227(1):222-231. [PubMed: 12668748]

99. Di Stefano F, Verna N, Di Giampaolo L, Boscolo P, Di Gioacchino M. Cavitating BOOP associated with myeloperoxidase deficiency in a floor cleaner with an incidental heavy exposure to benzalkonium compounds. J Occup Health. 2003; 45(3):182-184. [PubMed: 14646295]

100. Devakonda A, Raoof S, Sung A, Travis WD, Naidich D. Bronchiolar disorders: a clinicalradiological diagnostic algorithm. Chest. 2010; 137(4):938-951. [PubMed: 20371529]

101. Ryu JH. Classification and approach to bronchiolar diseases. Curr Opin Pulm Med. 2006; 12(2): 145-151. [PubMed: 16456385]

102. Chester EH, Kaimal J, Payne CB Jr, Kohn PM. Pulmonary injury following exposure to chlorine gas. Possible beneficial effects of steroid treatment. Chest. 1977; 72(2):247-250. [PubMed: 884993]

103. Epler GR, Colby TV, McLoud TC, Carrington CB, Gaensler EA. Bronchiolitis obliterans organizing pneumonia. N Engl J Med. 1985; 312(3):152-158. [PubMed: 3965933]

104. Spagnolo P, Fabbri LM, Bush A. Long-term macrolide treatment for chronic respiratory disease. Eur Respir J. 2013; 42(1):239-251. [PubMed: 23180583]

105. Shohrati M, Karimzadeh I, Saburi A, Khalili H, Ghanei M. The role of N-acetylcysteine in the management of acute and chronic pulmonary complications of sulfur mustard: a literature review. Inhal Toxicol. 2014; 26(9):507-523. [PubMed: 25055840]

106. Lai RS, Wang JS, Wu MT, Hsu HK. Lung transplantation in bronchiolitis obliterans associated with vegetable consumption. Lancet. 1998; 352(9122):117-118. [PubMed: 9672286]

107. Kreiss K. Flavoring-related bronchiolitis obliterans. Curr Opin Allergy Clin Immunol. 2007; 7(2): 162-167. [PubMed: 17351470]

108. Jones RN, Hughes JM, Glindmeyer H, Weill H. Lung function after acute chlorine exposure. Am Rev Respir Dis. 1986; 134(6):1190-1195. [PubMed: 3789518] 
109. Close LG, Catlin FI, Cohn AM. Acute and chronic effects of ammonia burns on the respiratory tract. Arch Otolaryngol. 1980; 106(3):151-158. [PubMed: 7356435]

110. Aldrich TK, Gustave J, Hall CB, et al. Lung function in rescue workers at the World Trade Center after 7 years. N Engl J Med. 2010; 362(14):1263-1272. [PubMed: 20375403]

111. van Rooy FG, Smit LA, Houba R, Zaat VA, Rooyackers JM, Heederik DJ. A cross-sectional study of lung function and respiratory symptoms among chemical workers producing diacetyl for food flavourings. Occup Environ Med. 2009; 66(2):105-110. [PubMed: 18805877]

112. Halldin CN, Suarthana E, Fedan KB, Lo YC, Turabelidze G, Kreiss K. Increased respiratory disease mortality at a microwave popcorn production facility with worker risk of bronchiolitis obliterans. PLoS ONE. 2013; 8(2):e57935. [PubMed: 23469109]

113. Turcotte SE, Chee A, Walsh R, et al. Flock worker's lung disease: natural history of cases and exposed workers in Kingston, Ontario. Chest. 2013; 143(6):1642-1648. [PubMed: 23699830]

114. Kern DG, Kern E, Crausman RS, Clapp RW. A retrospective cohort study of lung cancer incidence in nylon flock workers, 1998-2008. Int J Occup Environ Health. 2011; 17(4):345-351. [PubMed: 22069933]

115. Ould Kadi F, Abdesslam T, Nemery B. Five-year follow-up of Algerian victims of the "Ardystil syndrome". Eur Respir J. 1999; 13(4):940-941. [PubMed: 10362067]

116. Oppenheimer BW, Goldring RM, Herberg ME, et al. Distal airway function in symptomatic subjects with normal spirometry following World Trade Center dust exposure. Chest. 2007; 132(4):1275-1282. [PubMed: 17890470]

117. Todd JL, Wang X, Sugimoto S, et al. Hyaluronan contributes to bronchiolitis obliterans syndrome and stimulates lung allograft rejection through activation of innate immunity. Am J Respir Crit Care Med. 2014; 189(5):556-566. [PubMed: 24471427]

118. Kelly FL, Sun J, Fischer BM, et al. Diacetyl induces amphiregulin shedding in pulmonary epithelial cells and in experimental bronchiolitis obliterans. Am J Respir Cell Mol Biol. 2014; 51(4):568-574. [PubMed: 24816162]

119. Nord M, Schubert K, Cassel TN, Andersson O, Riise GC. Decreased serum and bronchoalveolar lavage levels of Clara cell secretory protein (CC16) is associated with bronchiolitis obliterans syndrome and airway neutrophilia in lung transplant recipients. Transplantation. 2002; 73(8): 1264-1269. [PubMed: 11981419]

120. Ziegenhagen MW, Zabel P, Zissel G, Schlaak M, Müller-Quernheim J. Serum level of interleukin 8 is elevated in idiopathic pulmonary fibrosis and indicates disease activity. Am J Respir Crit Care Med. 1998; 157(3, Pt 1):762-768. [PubMed: 9517588]

121. Egilman D, Mailloux C, Valentin C. Popcorn-worker lung caused by corporate and regulatory negligence: an avoidable tragedy. Int J Occup Environ Health. 2007; 13(1):85-98. [PubMed: 17427353]

122. Kass I, Zamel N, Dobry CA, Holzer M. Bronchiectasis following ammonia burns of the respiratory tract. A review of two cases. Chest. 1972; 62(3):282-285. [PubMed: 5056588]

123. Monforte V, Roman A, Gavaldá J, et al. Nebulized amphotericin B concentration and distribution in the respiratory tract of lung-transplanted patients. Transplantation. 2003; 75(9):1571-1574. [PubMed: 12792517]

124. Sobonya R. Fatal anhydrous ammonia inhalation. Hum Pathol. 1977; 8(3):293-299. [PubMed: 856718]

125. Simpson FG, Belfield PW, Cooke NJ. Chronic airflow limitation after inhalation of overheated cooking oil fumes. Postgrad Med J. 1985; 61(721):1001-1002. [PubMed: 4070105]

126. Sue MA. A moviemaker'smalady. N Engl J Med. 1999; 340(11):897. [PubMed: 10084914]

127. Boswell RT, McCunney RJ. Bronchiolitis obliterans from exposure to incinerator fly ash. J Occup Environ Med. 1995; 37(7):850-855. [PubMed: 7552470]

128. Spain BA, Cummings O, Garcia JG. Bronchiolitis obliterans in an animal feed worker. Am J Ind Med. 1995; 28(3):437-443. [PubMed: 7485196]

129. Arnold IMF, Dufresne RM, Alleyne BC, Stuart PJ. Health implication of occupational exposures to hydrogen sulfide. J Occup Med. 1985; 27(5):373-376. [PubMed: 3159860]

130. Parra O, Monsó E, Gallego M, Morera J. Inhalation of hydrogen sulphide: a case of subacute manifestations and long term sequelae. Br J Ind Med. 1991; 48(4):286-287. [PubMed: 2025598] 
131. Richardson DB. Respiratory effects of chronic hydrogen sulfide exposure. Am J Ind Med. 1995; 28(1):99-108. [PubMed: 7573079]

132. Doujaiji B, Al-Tawfiq JA. Hydrogen sulfide exposure in an adult male. Ann Saudi Med. 2010; 30(1):76-80. [PubMed: 20103963]

133. Weill H. Disaster at Bhopal: the accident, early findings and respiratory health outlook in those injured. Bull Eur Physiopathol Respir. 1987; 23(6):587-590. [PubMed: 3453752]

134. Mishra PK, Samarth RM, Pathak N, Jain SK, Banerjee S, Maudar KK. Bhopal Gas Tragedy: review of clinical and experimental findings after 25 years. Int J Occup Med Environ Health. 2009; 22(3):193-202. [PubMed: 19819837]

135. Figueiredo S, Morais A, Magalhães A, Souto Moura C, Almeida J, Gomes I. Occupational constrictive bronchiolitis with normal physical, functional and image findings. Rev Port Pneumol. 2009; 15(4):729-732. [PubMed: 19547903]

136. Grayson RR. Silage gas poisoning: nitrogen dioxide pneumonia, a new disease in agricultural workers. Ann Intern Med. 1956; 45(3):393-408. [PubMed: 13363168]

137. Yockey CC, Eden BM, Byrd RB. The McConnell missile accident. Clinical spectrum of nitrogen dioxide exposure. JAMA. 1980; 244(11):1221-1223. [PubMed: 7411784]

138. Borak J, Diller WF. Phosgene exposure: mechanisms of injury and treatment strategies. J Occup Environ Med. 2001; 43(2):110-119. [PubMed: 11227628]

139. Lai RS, Chiang AA, Wu MT, et al. Outbreak of bronchiolitis obliterans associated with consumption of Sauropus androgynus in Taiwan. Lancet. 1996; 348(9020):83-85. [PubMed: 8676721]

140. LaDue JS. Bronchiolitis fibrosa obliterans. Arch Intern Med. 1941; 68(4):663-673.

141. Seggev JS, Mason UG III, Worthen S, Stanford RE, Fernandez E. Bronchiolitis obliterans. Report of three cases with detailed physiologic studies. Chest. 1983; 83(2):169-174. [PubMed: 6822095]

142. Tasaka S, Kanazawa M, Mori M, et al. Long-term course of bronchiectasis and bronchiolitis obliterans as late complication of smoke inhalation. Respiration. 1995; 62(1):40-42. [PubMed: 7716354]

143. Janigan DT, Kilp T, Michael R, McCleave JJ. Bronchiolitis obliterans in a man who used his wood-burning stove to burn synthetic construction materials. CMAJ. 1997; 156(8):1171-1173. [PubMed: 9141990]

144. Charan NB, Myers CG, Lakshminarayan S, Spencer TM. Pulmonary injuries associated with acute sulfur dioxide inhalation. Am Rev Respir Dis. 1979; 119(4):555-560. [PubMed: 443628]

145. Weinberger B, Laskin JD, Sunil VR, Sinko PJ, Heck DE, Laskin DL. Sulfur mustard-induced pulmonary injury: therapeutic approaches to mitigating toxicity. Pulm Pharmacol Ther. 2011; 24(1):92-99. [PubMed: 20851203]

146. Tang FR, Loke WK. Sulfur mustard and respiratory diseases. Crit Rev Toxicol. 2012; 42(8):688702. [PubMed: 22742653] 

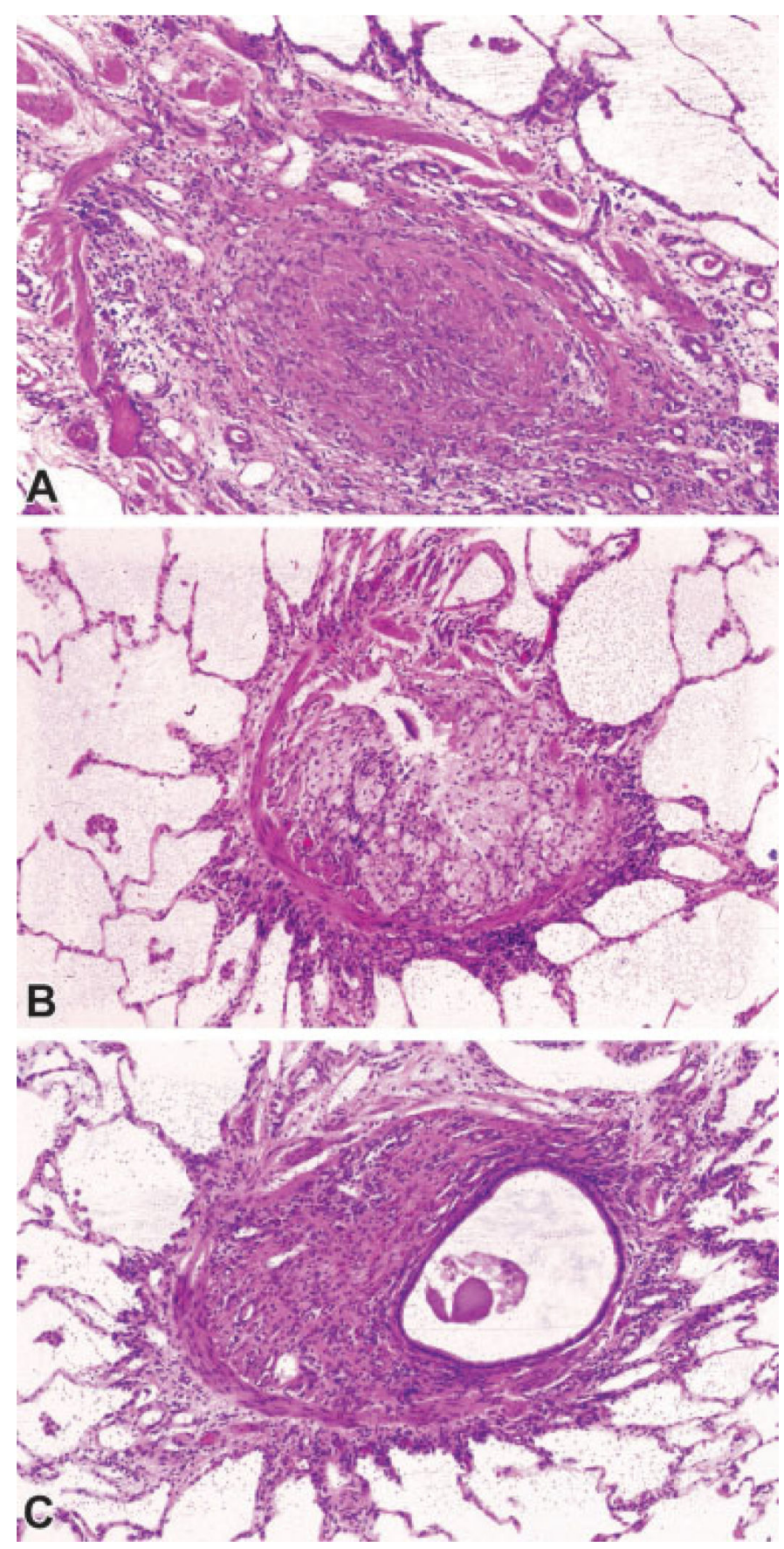

Fig. 1.

Constrictive bronchiolitis secondary to Sauropus androgynus ingestion. (A) The lumen of this bronchiole is completely obliterated by fibrous tissue. The smooth muscle layer is intact over the upper portion of the bronchiole. (B) A portion of the lumen of this bronchiole remains (upper center), whereas the remainder has been replaced by foamy histiocytes and a few chronic inflammatory cells. The smooth muscle layer is intact over the left and lower portions of the airway. (C) Eccentric obliteration of the bronchiolar lumen is apparent, with remaining lumen to the left and the rest replaced by fibrous tissue with a few inflammatory 
cells. The smooth muscle layer is partially intact over the left and lower portions of the airway. (Images courtesy of Dr. Victor Roggli, Department of Pathology, Duke University School of Medicine). 

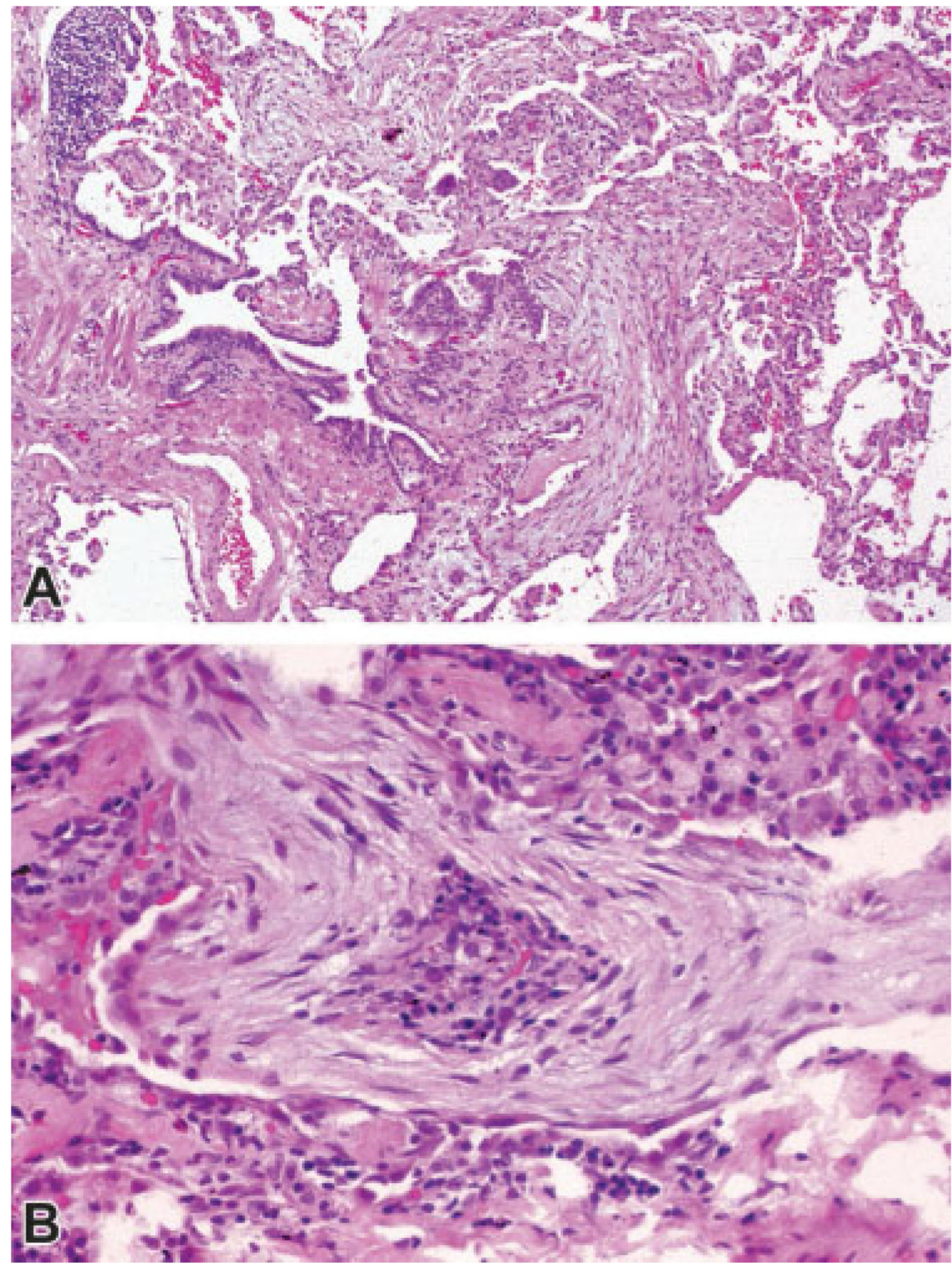

Fig. 2.

Bronchiolitis obliterans organizing pneumonia. (A) Low power view shows young edematous connective tissue plugs within alveoli and an alveolar duct, with projection into the lumen of a respiratory bronchiole (proliferative bronchiolitis). (B) High power view shows young edematous connective tissue plug within an alveolus. Note the partial lining by epithelium (bottom) and the chronic inflammatory cells near the center of the plug. (Images 
courtesy of Dr. Victor Roggli, Department of Pathology, Duke University School of Medicine). 


\section{Table 1}

Examples of known or suspected exposures causing bronchiolar disorders ${ }^{a}$

\begin{tabular}{|c|c|c|}
\hline Exposure & Illustrative setting & References \\
\hline Acramin FWN & Textile printing & $67-69$ \\
\hline Ammonia & Chemical industry, refrigerant & $93,109,122-124$ \\
\hline Benzalkonium compounds & Floor polish spill & 99 \\
\hline Bromine compounds & Flavoring research and development & 17 \\
\hline Chlorine & Transportation spill, industrial accident & $55,102,108$ \\
\hline Chlorine-liberating disinfectant (powder) & Cleaning & 55 \\
\hline Cooking oil fumes & Commercial cooking & 125 \\
\hline Diacetyl and 2,3-pentanedione & $\begin{array}{l}\text { Microwave popcorn, diacetyl manufacture, flavoring } \\
\text { manufacture, coffee roasting }\end{array}$ & $22-27,30,31$ \\
\hline Dimethyl disulfide & & 55 \\
\hline Dusts/gases/fumes & World Trade Center collapse & $51-53$ \\
\hline $\begin{array}{l}\text { Flock (fibers of nylon, polyethylene, polypropylene, } \\
\text { rayon) }\end{array}$ & $\begin{array}{l}\text { Upholstery, greeting cards, fishing nets manufacture, artificial } \\
\text { snow on movie set }\end{array}$ & $36,37,40,43-45,126$ \\
\hline Fly ash & Incineration of coal and oil & 127 \\
\hline Food production dusts (possibly flavorings) & Animal feed manufacture & 128 \\
\hline Humidifier disinfectant (polyhexamethylene guanidine) & Homes & 72,74 \\
\hline Hydrochloric acid & & 55 \\
\hline Hydrogen sulfide & Crude oil, natural gas, manure pits, toilets & 129-132 \\
\hline Methyl isocyanate & Bhopal pesticide manufacture leak & $63,65,133,134$ \\
\hline $\begin{array}{l}\text { Mineral dusts (aluminum oxide, asbestos, coal, iron } \\
\text { oxide, silica, others) }\end{array}$ & Coal mining, hard rock mining, photocopier toner & $54-56,135$ \\
\hline Oxides of nitrogen & $\begin{array}{l}\text { Explosive detonation, silage decomposition, nitric acid use, } \\
\text { nitrocellulose fires, welding gases }\end{array}$ & $7-15,18,19,136,137$ \\
\hline Phosgene & War gas, chemical manufacturing & 138 \\
\hline Polymethylene polyphenol isocyanate & Plastics factory maintenance & 93 \\
\hline Sauropus androgynus & Vegetable juice consumption for weight loss & 139 \\
\hline Shoe dye & Shoe shining parlor & 140 \\
\hline Smoke inhalation & $\begin{array}{l}\text { Plastics factory fire, synthetic materials in house fire, Styrofoam } \\
\text { combustion, photography processing fire (ammonia, nitrogen } \\
\text { dioxide) }\end{array}$ & $93,141-143$ \\
\hline Sulfur dioxide & Paper mill bleaching, sulfur mine fire & 16,144 \\
\hline Sulfur mustard & Chemical warfare & $46-50,145,146$ \\
\hline Thionyl chloride & Lithium battery manufacture & 20 \\
\hline
\end{tabular}

$a_{\text {Listed alphabetically by exposure. }}$ 
Table 2

Lung function patterns in cases of exposure-related bronchiolar disorders ${ }^{a}$

\begin{tabular}{|c|c|c|c|c|}
\hline Exposure & Histopathology & Spirometry & Diffusing capacity & References \\
\hline Nitrous oxide & Proliferative bronchiolitis & $\begin{array}{l}\text { Restriction (1/1) } \\
\text { Obstruction (3/3) } \\
\text { Obstruction (1/1) }\end{array}$ & $\begin{array}{l}\text { Low }(1 / 1) \\
\text { Low }(1 / 3) \\
\text { Low }(1 / 1)\end{array}$ & $\begin{array}{l}9 \\
10 \\
11\end{array}$ \\
\hline Diacetyl & Constrictive bronchiolitis & $\begin{array}{l}\text { Obstruction (2/9) } \\
\text { Restriction (1/9) } \\
\text { Mixed (6/9) }\end{array}$ & Low $(2 / 7)$ & 23 \\
\hline $\begin{array}{l}\text { Fiberglass-reinforced } \\
\text { plastics (possibly styrene) }\end{array}$ & Constrictive bronchiolitis & $\begin{array}{l}\text { Obstruction (6/6) } \\
\text { Obstruction }(2 / 2)\end{array}$ & & $\begin{array}{l}32 \\
33\end{array}$ \\
\hline Nylon flock & Lymphocytic bronchiolitis, peribronchiolitis & $\begin{array}{l}\text { Obstruction (3/20) } \\
\text { Restriction (10/20) } \\
\text { Normal (2/5) } \\
\text { Restriction (3/5) }\end{array}$ & $\begin{array}{l}\text { Low }(13 / 19) \\
\text { Low }(4 / 4)\end{array}$ & $\begin{array}{l}37 \\
39\end{array}$ \\
\hline Sulfur mustard & BOOP, constrictive bronchiolitis, other & $\begin{array}{l}\text { Obstruction }(1 / 1) \\
\text { Obstruction }(1 / 1) \\
\text { Normal }(13 / 15) \\
\text { Obstruction }(1 / 15) \\
\text { Restriction }(1 / 15)\end{array}$ & Normal (23/23) & $\begin{array}{l}46 \\
47 \\
49 \\
50\end{array}$ \\
\hline $\begin{array}{l}\text { World Trade Center dust/ } \\
\text { gases/fumes }\end{array}$ & $\begin{array}{l}\text { Constrictive bronchiolitis; nondiagnostic } \\
\text { bronchiolar abnormalities }\end{array}$ & $\begin{array}{l}\text { Mixed (1/1) } \\
\text { Normal (1/7) } \\
\text { Restriction (5/7) } \\
\text { Mixed (1/7) } \\
\text { Restriction (5/8) } \\
\text { Mixed (3/8) }\end{array}$ & $\begin{array}{l}\text { Low }(1 / 1) \\
\text { Low }(3 / 5) \\
\text { Low }(8 / 8)\end{array}$ & $\begin{array}{l}51 \\
52 \\
53\end{array}$ \\
\hline $\begin{array}{l}\text { Sulfur mine fire, other } \\
\text { combustion or dust }\end{array}$ & Constrictive bronchiolitis & $\begin{array}{l}\text { Normal }(32 / 38) \\
\text { Obstruction }(2 / 38) \\
\text { Restriction }(3 / 38) \\
\text { Mixed }(1 / 38)\end{array}$ & Low $(23 / 38)$ & 61 \\
\hline Acramin FWN (textile dye) & BOOP & $\begin{array}{l}\text { Normal }(7 / 14) \\
\text { Restriction }(5 / 14) \\
\text { Obstruction }(2 / 14)\end{array}$ & Low $(1 / 14)$ & 69 \\
\hline Humidifier disinfectant & $\begin{array}{l}\text { Constrictive bronchiolitis, BOOP, acute } \\
\text { changes }\end{array}$ & Restriction (9/9) & $\begin{array}{l}\text { Mean DLCO 41\% } \\
\text { predicted }\end{array}$ & 74 \\
\hline
\end{tabular}

${ }^{a}$ Listed in order of citation in text. Abnormalities are shown as reported in the publications. Reference equations and interpretative strategies were not uniform across studies, which may have introduced some misclassification. Nonetheless, a spectrum of findings is evident. 